\title{
Designing The Autogate Pass Dashboard Application with Android based Responsive Web Design Technology
}

\author{
Tata Sutabri ${ }^{1}$, Hesti Rian ${ }^{2}$, Prionggo Hendradi ${ }^{3}$, Febrianto $^{4}$ \\ \{tata.sutabri@gmail.com ${ }^{1}$, hestiriangustiawan@gmail.com ${ }^{2}$, prionggo.hendradi@gmail.com ${ }^{3}$, \\ febrianrian.fr97@gmail.com $\left.{ }^{4}\right\}$
}

\begin{abstract}
Faculty of Information Technology, University of Respati Indonesia, Jakarta ${ }^{1}$, Management of Information Program, Polytechnic of LP3I Jakarta, Indonesia ${ }^{2}$, Faculty of Technical, University of Satya Negara Indonesia, Jakarta, Indonesia ${ }^{3}$, Faculty of Computer, University of MH.Thamrin, Jakarta, Indonesia ${ }^{4}$
\end{abstract}

\begin{abstract}
Autogate Pass Dashboard application is an application that provides convenience for users in monitoring and analyzing object data. This dashboard application is a technology used to present information, on a large scale, fast (realtime), concise and detailed with the support of an attractive visual display. Autogate Pass Dashboard application with Responsive Web Design technology, aims to provide convenience in terms of monitoring vehicle data in and out of the Tanjung Priok Port area in an interactive, real time, dynamic, and relevant and compatible way on Android devices. The dashboard design method begins with analyzing the process of monitoring object data, determining data requirements, determining data access schemes, user analysis, determining content, creat ing dashboard designs, and creating interaction scenarios between users and dashboards. The results of this study are in the form of applications that can process information related to object data, such as vehicle data entering and leaving the PT. Pelabuh an Indonesia II Tanjung Priok, so as to make it easy to analyze and monitor vehicle data that operate every day in the form of bar charts, pies, tables on a regular and dynamic basis.
\end{abstract}

Keywords: Dashboard application, responsive web design, android devices, autogate pass

\section{Introduction}

Access to the Port of Tanjung Priok Indones ia II, still uses a manual process, namely with paper tickets and cash payments. In the process there are several shortcomings, as follows :

1. The number of vehicles in operation continues to increase

2. Income reports are done manually

3. There is no previous statis tical data of vehicles entering the Tanjung Priok Port area

4. There is no control of income, so there are often losses from the daily pas s income of the Port.

Based on the shortcomings of these conditions, an Electronic Gate Pass solution is needed. With Electronic Gate Pass payments can be made by e-money such as toll roads, there are also consolidated income reports fromeach gate, as well as vehicle statistics coming into the port. Therefore the Autogate System application is made at each post in the port area. Autogate System is an electronic system that is used to open and close gates or barriers when a vehicle will pass automatically, and make gate pass pay ments electronically. This application has also been equipped with a database to store all data from each vehicle entering the Port of Indonesia II Tanjung Priok area.

The Autogate Pass Dashboard application does not capture data fromevery vehicle entering and leaving the PT. Indonesia Port II Tanjung Priok directly. The data of each vehicle is captured by another application, the Autog ate System Application. After the data is captured the data is stored in the Autogate System Database. The Autogate Pass Dashboard application accesses and processes data for each vehicle in the Autogate System Database. The Autogate Pass Dashboard application can display vehicle data in and out of the Port of Tanjung area from the Autogate Systemdatabase. The following information is dis played:

1. Income data at each post, and type of vehicle integrated with the vehicle data source database.

2. Vehicle traffic data conducting transactions at each post.

In the running system process, traffic reports and vehicle revenues coming in and out of the Port of Tanjung Priok Indonesia II area are still lacking, such as:

1. The data analysis process is not efficient because it goes through a long process from the initial request of vehicle data to the Vendor Autogate System until the data is processed by the Information System division of PT. Tanjung Priok Port II of Indonesia. 
2. Monitoring of vehicle data in and out of the Port of Indonesia II Tanjung Priok area is inflexible, because the availability of reports is only through the excel PivotTabel document which is processed by PT. Tanjung Priok Port II of Indonesia.

3. The report displayed is less interactive because it is in the form of an excel PivotTable which can only display a summary formof the report simply.

To further maximize the performance of the traffic report system and the revenue of vehicles entering and exiting the Tanjung Priok Port II area, an altemative system problem is needed. The proposed problem solving is by developing applications that are able to provide information on traffic data reports and vehicle revenues that enter the area of PT. Pelabuhan Indonesia II Tanjung Priok takes the form of a web-based dashboard with responsive web design technology with the following facilities:

1. Facility of checking vehicle traffic data in the form of applications that can be accessed on various devices (mobile, tablet, desktop) in realtime, interactive and dynamic.

2. Facility of income data reports in the form of applications that can be accessed on various devices (mobile, tablet, desktop) in real time, interactive and dynamic.

3. Download and print traffic reports and revenue reports in Excel and PDF documents directly through the application that will be created.

\section{Research Methodology}

The application development method uses the waterfall methodology, this is because this method uses a structured systems approach so that each stage must be completed first in full before continuing to the next stage, with the aim of avoiding repetition of these stages. This makes all system requirements can be defined completely, explicitly, and correctly at the beginning of the project, so that Software Engineering can run smoothly and without problems. The waterfall procedure is as follows:

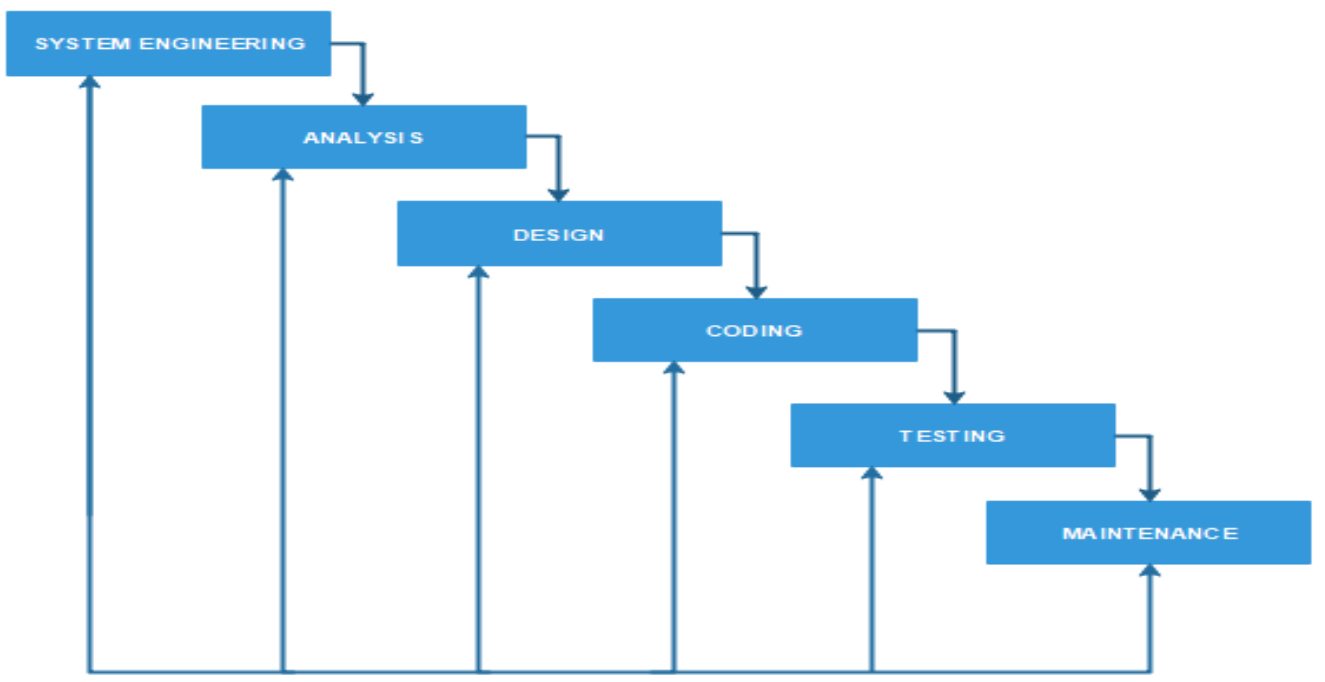

Fig. 1.1 Waterfall Methodology

1. Systems engineering, is the manufacture of software which is the largest part of a project. For work begins with determining all the things that are necessary in the implementation.

2. Analysis, is the stage where system engineering analyzes the things that are shown in the implementation of a project making or application development and aims to understand the existing system, identify problems and find solutions.

3. Design, this stage is the trans lation stage of the needs or data that has been analyzed into a form that is easily understood by the user. At this stage, a dashboard mockup design process is made that indicates how the interface and the placement of the dashboard components are made.

4. Code, which trans lates data or problems olving designed into a predetermined programming language. 
5. Testing. After the program has been completed, the next stage is testing the program. Evaluation and testing of the appropriateness between the appearance of the application and the design has been made and the data validation process between the representative data in the dashboard and the raw data used as the data source (Autogate System database).

Maintenance was the implementation of the whole accompanied by maintenance in case of structural changes, both in terms of software and hardware.

\section{Discussion}

The benefit of designing this Autog ate Pass Dashboard application is to optimize reports of vehicles entering the PT. Pelabuhan Indonesia II Tanjung Priok. This application is integrated with the Autogate System database which is a source of data for vehicles entering the PT. Pelabuhan Indonesia II Tanjung Priok. The system procedure proposed in the Autogate Pass Dashboard application is as follows:

a) Adminis trators enter user data who can log into the AutogatePass dashboard application.

b) Adminis trators differentiate access rights or roles between Pelindo users and non Pelindo users.

c) Pelindo users can access traffic and revenue pages to search for statistical data and income based on the search date period.

d) Pelindo users can monitor traffic and income data online.

e) Non-Pelindo users can only access the traffic page to be able to find out the traffic of vehicles in and out of the Tanjung Priok II Port of Indonesia.

f) Administrators can access user management and role management pages for configuring users registered to the Autogate Pass dashboard application.

g) Pelindo users can export reports on the Dashboard Autogate Pass application into excel and pdf reports.

In this research, a use case diagram is designed that describes the processes that occur between actors and use cases involved in the system.

\section{Use Case Diagram-ManageAccount}

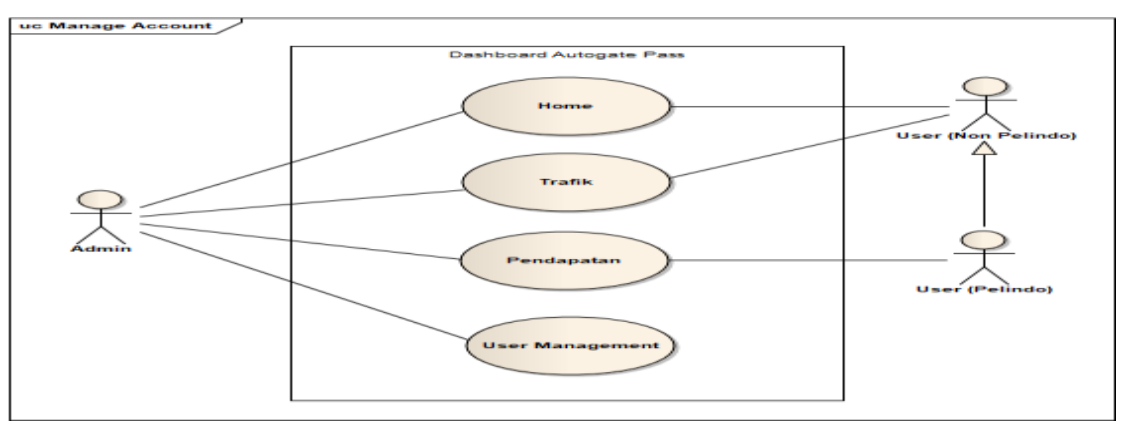

Fig.1.1 Use Case Diagram Manage Account Dashboard Autogate Pass

2. Activity Diagram User Management

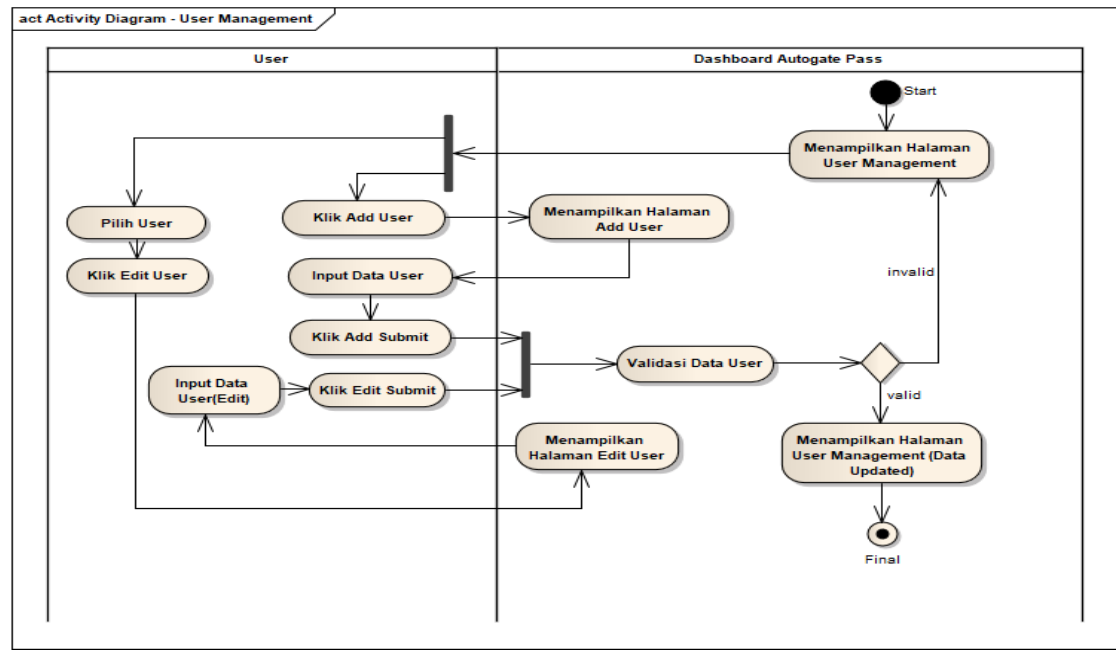

Fig. 1.3 Activity Diagram User Management 


\section{Class Diagram Dashboard Autogate Pass}

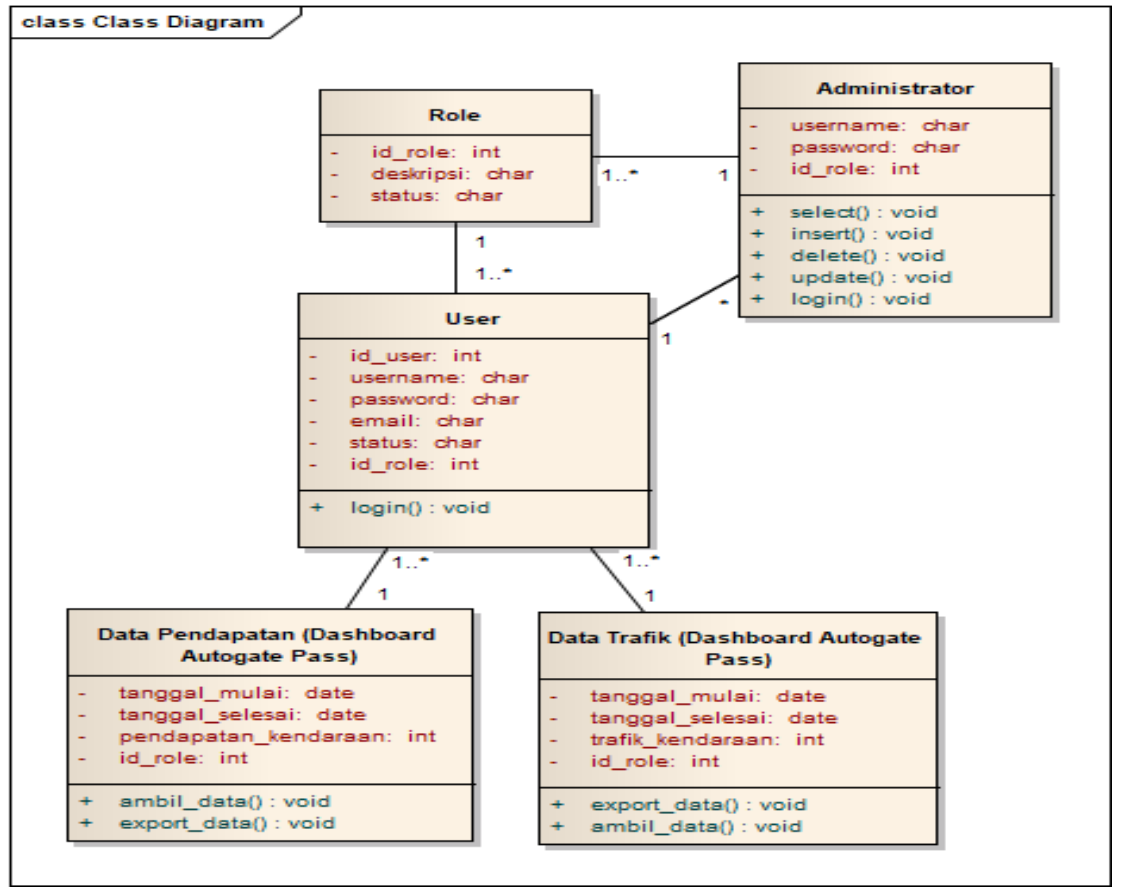

Fig. 1.4 Class Diagram Dashboard Autogate Pass

\section{Sequence Diagram User Management}

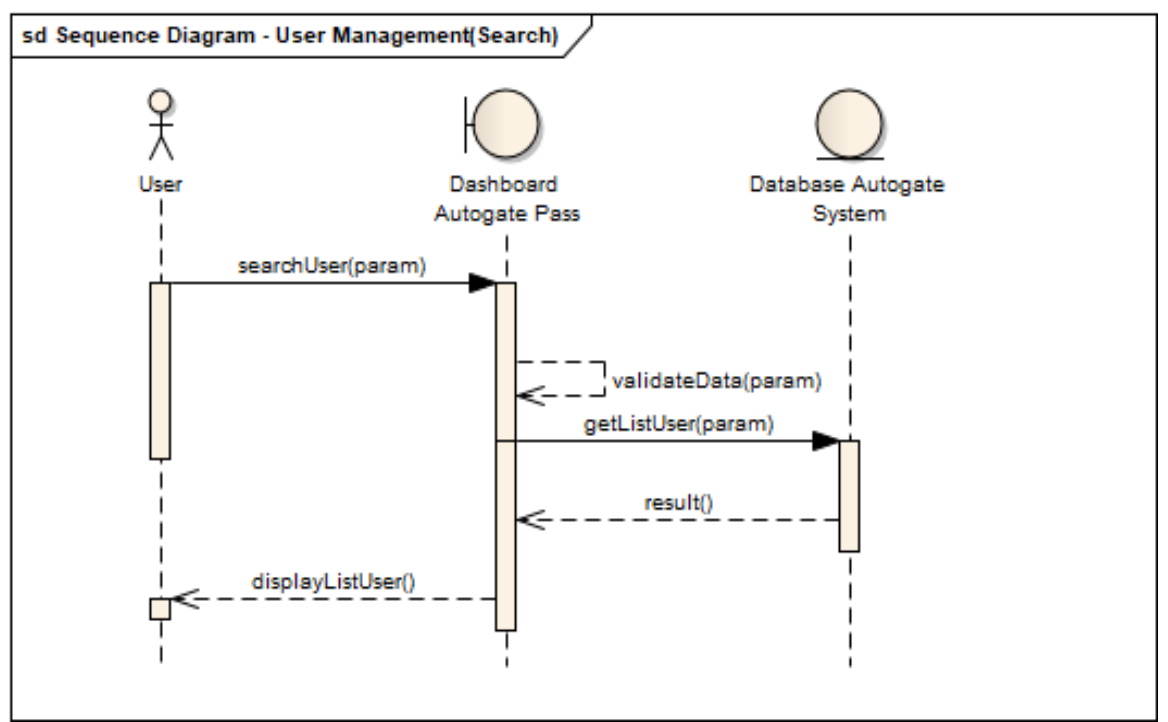

Fig. 1.2 Sequence Diagram User Management

In the next stage, a dashboard mockup design is created which indicates how the interface and the placement of the dashboard components are made. 
1. Mockup of menu login and signup

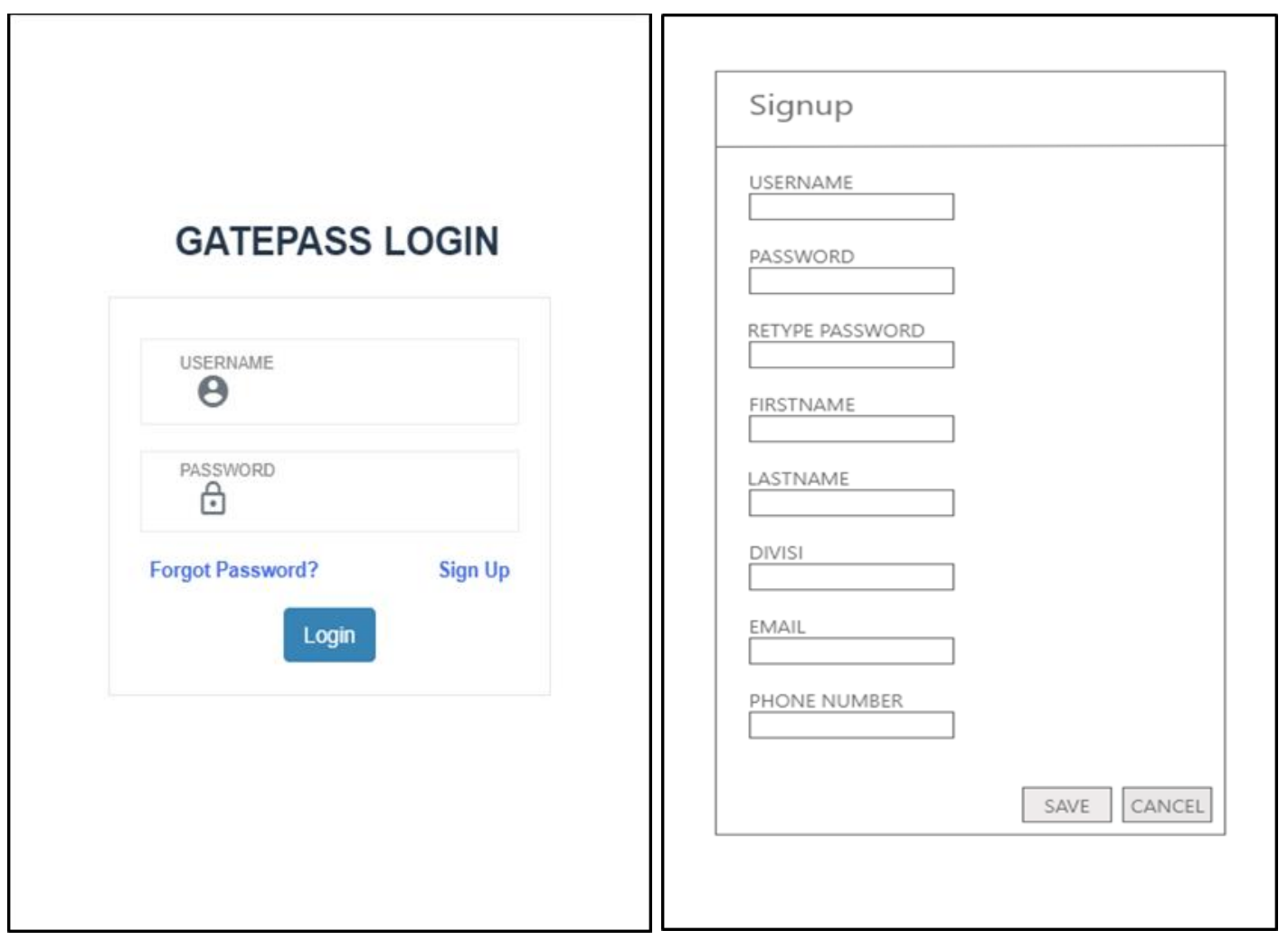

2. Mockup of navigation page view

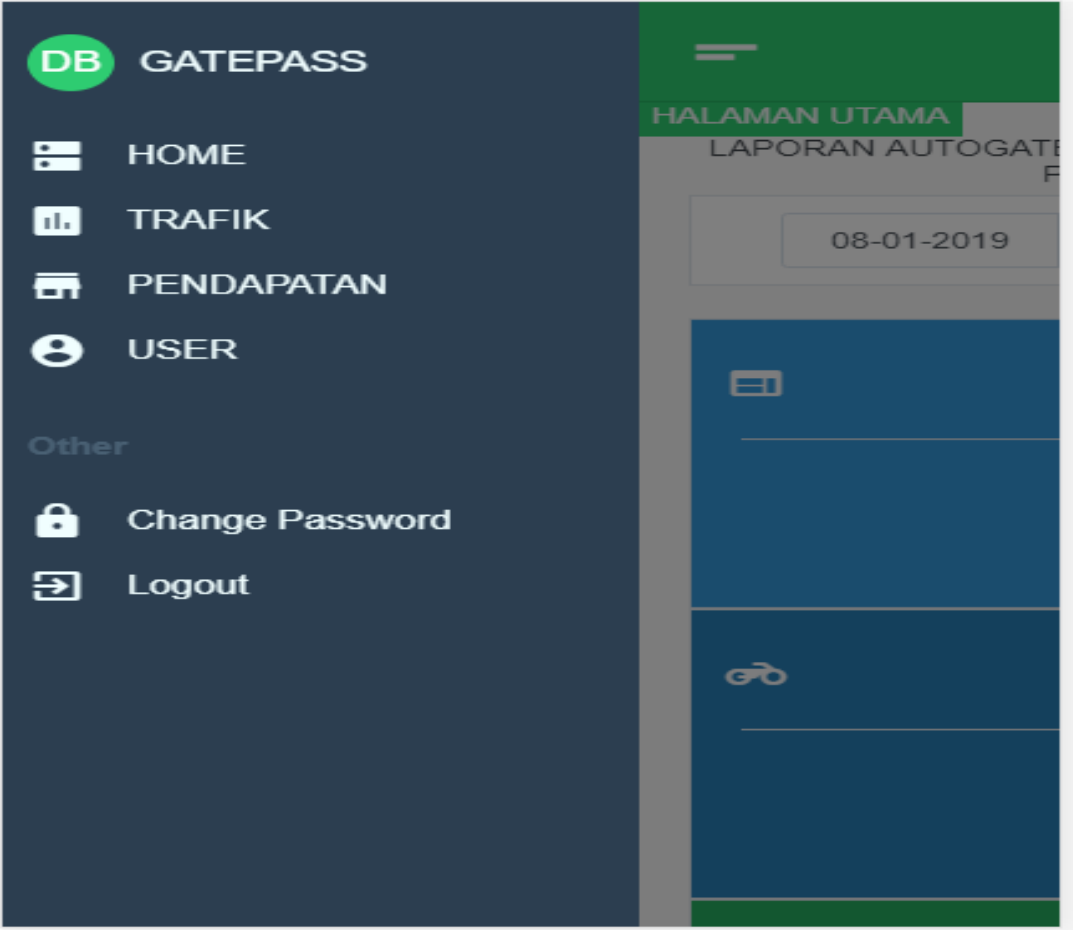


3. Mockup of home page view

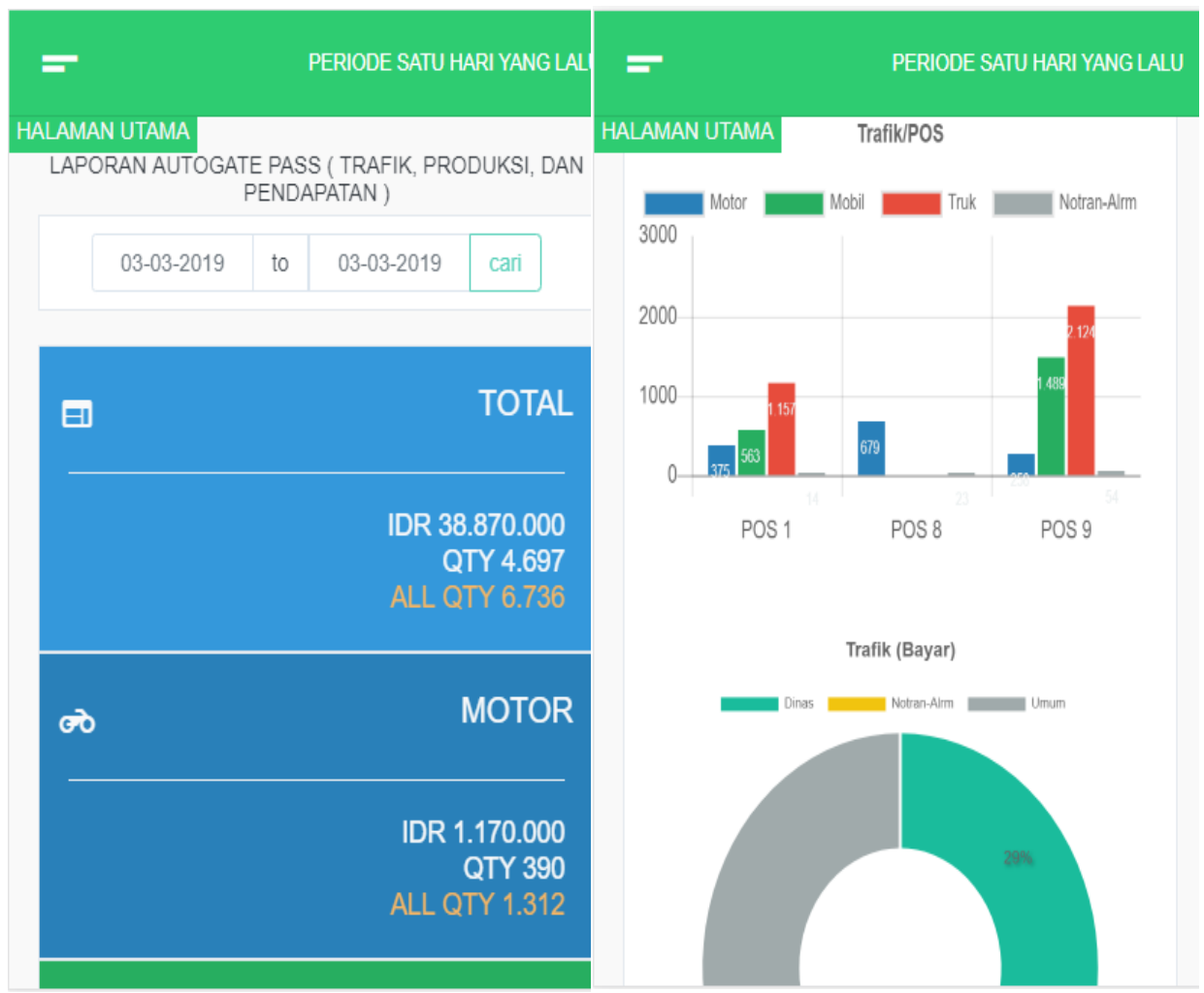

4. Mockup of revenue menu dis play

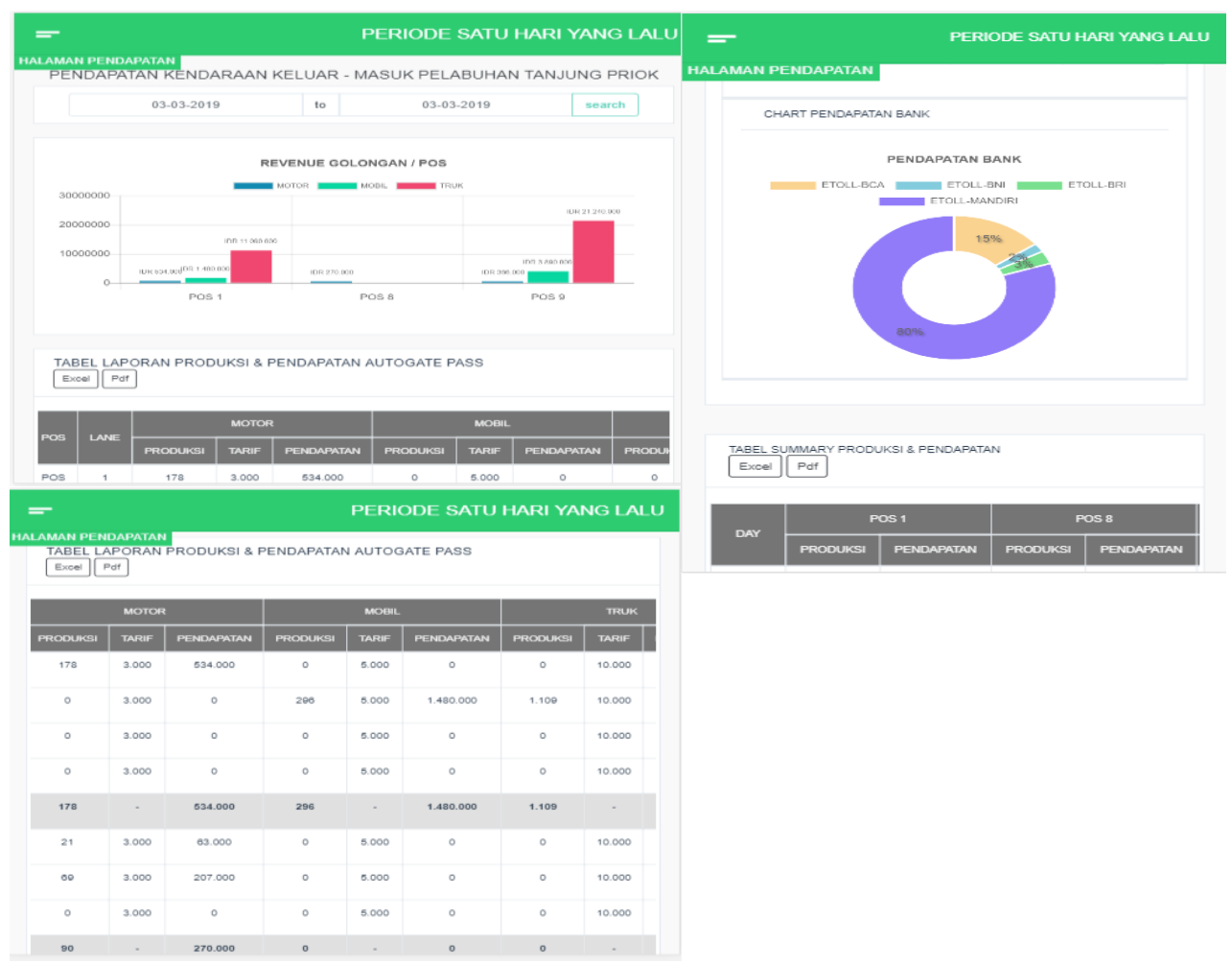




\section{Mockup of traffic menu display}

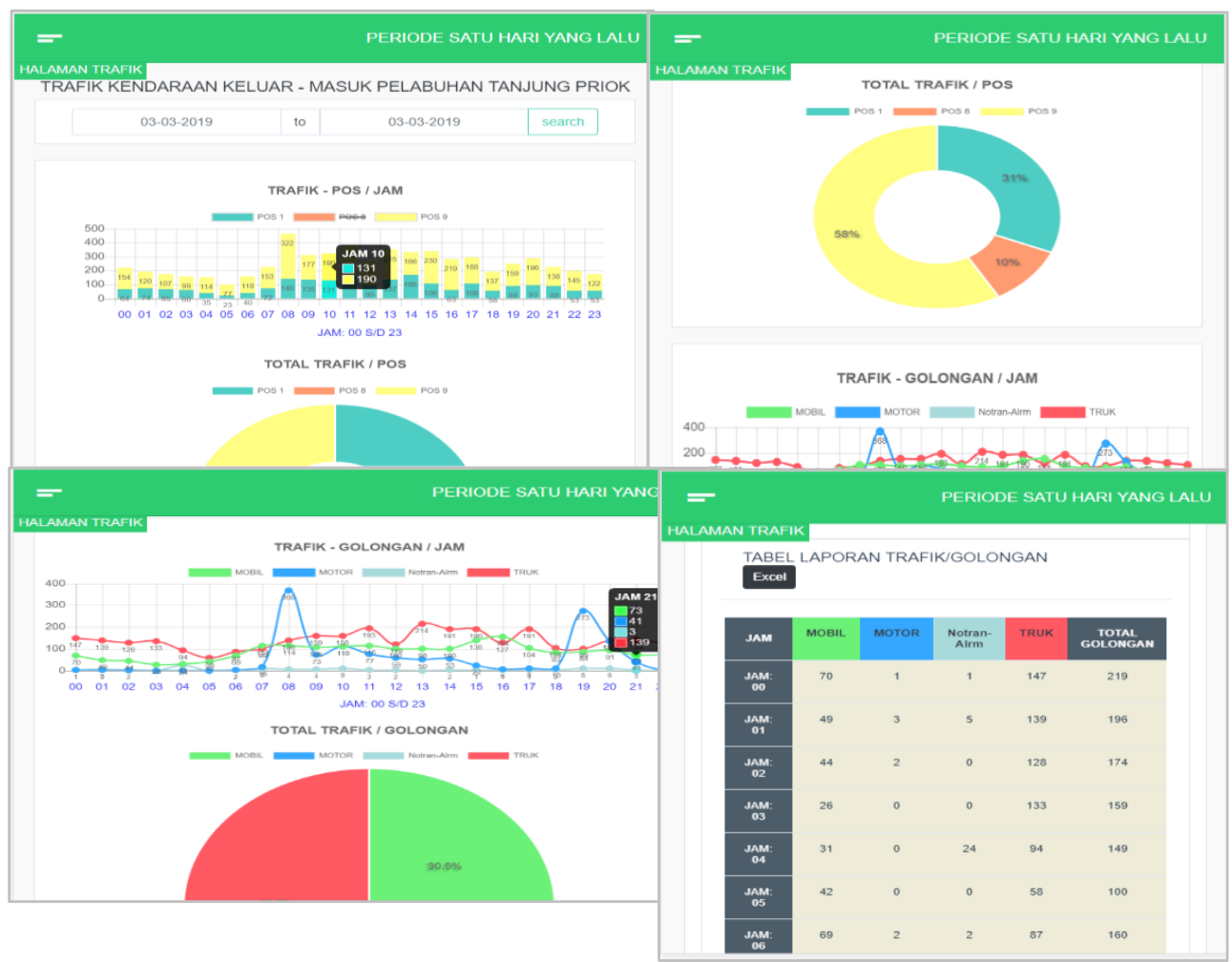

\section{Conclusion}

The Autogate Pass Dashboard application can make it easier for PT. Pelabuhan Indonesia II in terms of monitoring through a dashboard which is displayed interactively in the form of bar graphs, pies, tables, and report documents regarding periodic and dynamic information on revenue data and vehicle statistics. The Dashboard application, vehicle traffic data can be accessed on various devices (mobile, tablet, desktop) in realtime, interactive and dynamic. The income data report for each type and class of vehicles can be accessed on various devices (mobile, tablet, desktop) in realtime, interactive and dynamic. The Autogate Pass Dashboard application that runs online, Pelindo Users (Pelabuhan Indonesia) and Non Pelindo Users can monitor vehicle data reports efficiently and flexibly. The Autogate Pass Dashboard application, the process of analyzing data becomes easier and more efficient, compared to analyzing data from the database directly. The Autogate Pass Dashboard application can be used as a means of support during the decision-making process carried out by company leaders. The Autogate Pass Dashboard application, the process of making vehicle data reports in and out of the port area of Indonesia II Tanjung Priok is increasingly effective and fast.

\section{References.}

[1] Agus, Prayitno, and Yulia Safitri. 2015. "Pemanfaatan Sistem Informasi Perpustakaan Digital Berbasis Website Untuk."

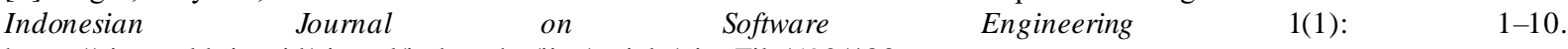
https://ejournal.bsi.ac.id/ejurnal/index.php/ijse/article/viewFile/592/483.

[2] Arman. 2016. "Sistem Informasi Pengolahan Data Penduduk Nagari Tanjung Lolo, Kecamatan Tanjung Gadang, Kabupaten Sijunjung Berbasis Web.” Jurnal Edik Informatika Penelitian Bidang Komputer Sains dan Pendidikan Informatika V2.i2(163-170) 55(5): 163-70.

[3] Azhary, Wijayanto and Hadiyokso. 2016. "Design and Implementation House Lamp Controling System Based on Adroid Using Raspberry-Pi.” 3(3): 4838-43.

[4] Betha Sidik. Pemrograman Web dengan PHP7. Bandung: Informatika, 2017.

[5] Budi Raharjo. Belajar Otodidak Framework Codeigniter. Bandung: Informatika, 2018. 
[6] Muhamad. Model Waterfall Pada Desain Sistem Informasi Pendaftaran. "Sentra Penelitian Engineering dan Edukasi 10(2).T abrani. 2017.

[7] Prayitno Hidayatullah. VISUAL BASIC.NET Membuat Aplikasi Database dan Program Kreatif. Bandung: Informatika, 2015.

[8] Ropianto, Muhammad. 2017. "Pemanfaatan Sistem Dashboard Pada Data Akademik Di Sekolah Tinggi Teknik ( STT ) Ibnu Sina Batam.”Jurnal Teknik Ibnu Sina JT-IBSI 2(2): 67-71.

[9] Rosa A. S dan M. Salahudin. Rekayasa PerangkatLunak. Bandung: Informatika, 2016.

[10] R.H. Sianipar. HTML5 dan CSS3 Belajardari Kasus. Bandung: Informatika, 2015.

[11] Santoso, Miftah Faroq. 2018. "Teknik Responsive Web Design Bootstrap 4 Serta Penerapannya Dalam Rancang Bangun Layout Web." Konferensi Nasional Sistem \& Informatika 2(2): 61-68. https://ejournal.bsi.ac.id/ejurnal/index.php/ijse/article/viewFile/592/483.

[12] Sire gar, Helmi Fauzi, Yustria Handika Siregar, and Melani. 2018. "Perancangan Aplikasi Komik Hadist Berbasis Multimedia." Teknologi Informasi 2(2): 113-21.

[13] Sutabri, T., Suryatno, A., Setiadi, D., \& Negara, E. S. (2018, October). Improving Naïve Bayes in Sentiment Analysis For Hotel Industry in Indonesia. In 2018 Third International Conference on Informatics and Computing (ICIC) (pp. 1-6). IEEE.

[14] Suharsana, I Ketut. 2015. "Perancangan Sistem Informasi Eksekutif Perkara Pada Pengadilan Negeri Wilayah Provinsi Bali." Konferensi Nasional Sistem \& Informatika:9-10.

[15] Syahrul. 2018. "Aplikasi Monitoring Proses Marketing Divisi Penerimaan Mahasiswa Baru ( Pmb ) ( Studi Kasus: Amik Tri Dharma Pekanbaru )." Informatika, Manajemen dan Komputer, Vol. 10 No. 2, Desember 2018 10(2): 8-12. http://ejournal.stmikdumai.ac.id/index.php/path/article/viewFile/109/47.

[16] Zulhalim. 2018. "Aplikasi Surat Perjalanan Dinas Dalam Negeri Menggunakan Visual Basic . Net , Postgresql Dan." 2(1). 